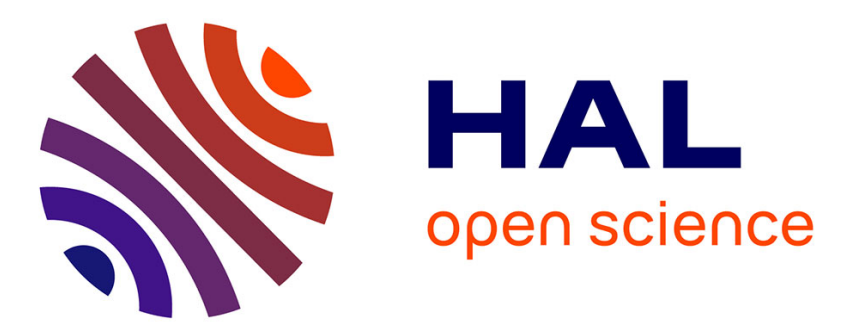

\title{
Differential environmental effects on caste allocation in two Amazonian Melipona bees
}

\author{
Diana Brito, Raquel Nunes, Pedro Pequeno, Carlos Nunes-Silva, Gislene
}

Carvalho-Zilse

\section{- To cite this version:}

Diana Brito, Raquel Nunes, Pedro Pequeno, Carlos Nunes-Silva, Gislene Carvalho-Zilse. Differential environmental effects on caste allocation in two Amazonian Melipona bees. Apidologie, 2013, 44 (6), pp.666-672. 10.1007/s13592-013-0215-8 . hal-01201335

\section{HAL Id: hal-01201335 \\ https://hal.science/hal-01201335}

Submitted on 17 Sep 2015

HAL is a multi-disciplinary open access archive for the deposit and dissemination of scientific research documents, whether they are published or not. The documents may come from teaching and research institutions in France or abroad, or from public or private research centers.
L'archive ouverte pluridisciplinaire HAL, est destinée au dépôt et à la diffusion de documents scientifiques de niveau recherche, publiés ou non, émanant des établissements d'enseignement et de recherche français ou étrangers, des laboratoires publics ou privés. 


\title{
Differential environmental effects on caste allocation in two Amazonian Melipona bees
}

\author{
Diana Vieira Brito ${ }^{1}$, Raquel Amazonas da Silva Nunes ${ }^{1}$, \\ Pedro Aurélio Costa Lima PeQueno ${ }^{1}$, Carlos Gustavo Nunes-Silva ${ }^{2}$, \\ Gislene Almeida CARVALHO-ZILSE ${ }^{1}$

\begin{abstract}
${ }^{1}$ Coordenação de Biodiversidade, Instituto Nacional de Pesquisas da Amazônia, Manaus 69080-971, Amazonas, Brasil
${ }^{2}$ Instituto de Ciências Biológicas, Universidade Federal do Amazonas, Av. General Rodrigo Otávio, 6200, Coroado,
\end{abstract} \\ Manaus 69077-000, Amazonas, Brasil
}

Received 5 October 2012 - Revised 23 April 2013 - Accepted 13 May 2013

\begin{abstract}
In Melipona bees, gyne proportion is exceptionally high in relation to other genera of eusocial bees. However, hypotheses on caste determination in this genus predict gyne proportions above those usually observed. This may be because gyne production is limited by environmental conditions. Our aim was to investigate the influence of environmental factors on caste allocation in two species in the genus Melipona. Monthly caste production was monitored for almost 2 years. In Melipona interrupta, gyne proportion was negatively correlated to cumulative rainfall. However, in Melipona seminigra, caste allocation did not depend on environmental factors. Comparison among these and other congeneric species suggests that this variation reflects the diversity of food sources. Thus, although the mechanism of caste determination may be common to Melipona spp., caste allocation across species responds differently to environmental constraints.
\end{abstract}

\section{eusocial insects / foraging / Meliponini / queen / stingless bees}

\section{INTRODUCTION}

Division in reproductive and non-reproductive castes in social insects determines remarkable differences in the physiology, behavior, and morphology of individuals of the same species (Grimaldi and Engel 2005). In species from Hymenoptera whose queens and workers differ morphologically, caste is irreversibly determined in the immature stage (Bourke and Ratnieks 1999). Thus, the allocation of resources for the production of workers or reproductives during oviposition is crucial in determining colony fitness and, thus, guaranteeing its maintenance, growth, and reproduction (Mitesser et al. 2007).

Corresponding author: D.V. Brito, diana.vieira.brito@gmail.com

Manuscript editor: James Nieh
For instance, in the honeybee Apis mellifera, gynes are produced only when necessary, in small quantities, and males are numerous only during the reproductive period. However, in the neotropical stingless bee genus Melipona, reproductives are often produced year-long and gyne numbers are exceptionally high, even with a low rate of swarming (Ratnieks 2001; Sommeijer et al. 2003). Part of this phenomenon can be explained by the peculiar system of caste determination found in this genus.

Differently from other eusocial bee species, Melipona's workers, gynes, and males are raised in same-sized cells, which receive massprovisioning, and neither quantitative nor qualitative differences primarily determine which female larvae turn into queens or workers (Kerr 1950; Hartfelder et al. 2006). Kerr (1950) and Kerr et al. (1966) proposed that there is a 
genetic predisposition in caste determination in Melipona, and the segregation of caste-specific genotypes results in the production of about $25 \%$ of gynes. Alternatively, Ratnieks (2001) proposed a caste self-determination hypothesis to explain Melipona's traits. Given the peculiarities of broodrearing in Melipona, workers have a limited control over caste fate. Under those conditions, 14 to $20 \%$ of the female larvae are expected to self-determine their fate and become queens.

So far, the genetic predisposition hypothesis has had more empirical evidences (Bonetti 1984; Camargo et al. 1976; Kerr et al. 1975; Kerr and Nielsen 1966), though these hypotheses are not mutually exclusive. Still, the observed gyne proportion in Melipona colonies often varies below the expected under both hypotheses (Kerr et al. 1966; Koedam 1999; Moo-Valle et al. 2001; Morais et al. 2006; Sommeijer et al. 2003; van Veen et al. 2004). This may happen because caste allocation is subject not only to the aforementioned factors, but also to limitation imposed by the environment.

Even though differential feeding is not the initial trigger for caste determination in Melipona, studies have shown that feeding interferes in the expression of the gyne phenotype. A threshold amount of food is required for queen growth and differentiation, below which there is no gyne development (Kerr et al. 1966). A restriction of certain components in female larvae diet can also interfere in gyne differentiation and decrease their proportion in the colony (Jarau et al. 2010). As the main sources of food for bees are pollen and nectar, environmental conditions that affect flowering may influence caste allocation. Reproductive patterns of plants in tropical forests are correlated to seasonal climatic factors such as rainfall (Smith-Ramirez and Armesto 1994), temperature (Chang-Yang et al. 2012), and day length or photoperiod (Morellato et al. 2000). Moreover, factors that interfere in the flight activity of bees, such as temperature and air humidity (Carvalho-Zilse et al. 2007; Oliveira et al. 2012; Silva et al. 2011), may also influence colony foraging and food supply.

Here, our objective was to describe colony phenotype allocation (sex and caste) and to investigate the effect of environmental factors (temperature, rainfall, daily hours of sunshine, and air humidity) on gyne proportion in two stingless bee species: Melipona interrupta Latreille (syn. Melipona compressipes manaosensis) and Melipona seminigra Friese. These are the most cultivated stingless bee species in Northern Brazil and differ substantially in biological features such as chromosomal number (Francini et al. 2011) and mating systems (Francini et al. 2012).

\section{MATERIALS AND METHODS}

\subsection{Bee sampling}

Six colonies from each species were sampled. Colonies were reared in the meliponary of the Bee Research Group (GPA) at the National Institute of Amazonian Research (INPA), Manaus, Amazonas, Brazil. Colonies were monitored monthly during 22 months for $M$. interrupta and 20 months for $M$. seminigra. Each month, we collected one brood comb from each colony, containing individuals in early pupal stage (approximately 30 days after oviposition). Individuals were identified regarding sex and caste with a stereomicroscope.

\subsection{Environmental data}

Environmental data for the city of Manaus during the sampling period were obtained from the meteorological database of the National Institute for Meteorology (INMET; Estação 82,331, Manaus, AM) (http:// www.inmet.gov.br/portal/index.php?r=bdmep/bdmep). Data were originally recorded on a daily basis, and we then computed monthly averages of temperature (degrees Centigrade), daily sunshine (hours) and air humidity (percent), and monthly cumulative rainfall (millimeters). Additionally, a thermohygrometer was installed in the meliponary in order to compare local environmental conditions to the climatic data.

\subsection{Statistical analysis}

We calculated the monthly gyne proportion (total number of gynes/total number of females, pooled across all six colonies) and male proportion (total number of males/total number of individuals, pooled across all six colonies) to infer variation in sex and caste allocation through time. Then, we used gener- 
alized linear models (GLM) with logit link and binomial errors (corrected for overdispersion) to test whether the probability of gyne proportion varied as a function of male proportion. Furthermore, we used chi-square tests to determine if the number of gynes produced in a month was statistically different from the caste segregation expected under the hypothesis of genetic predisposition (3:1 workers to gyne). We also used chi-square tests to verify the presence of diploid males, since the expected sex ratio in a comb when diploid male are being produced is of 1:1 male to female (Francini et al. 2012), and the frequency of haploid males is typically lower than this (Kerr 1996).

The probability of gyne proportion per month was analyzed as a function of the environmental variables utilizing GLM with logit link and binomial errors, corrected for overdispersion. In these analyses, we compared the gyne proportion to environmental data related to the previous month, in order to make inferences about environmental conditions during oviposition (i.e., when food availability is necessary for mass-provisioning of brood cells), which occurs about a month before gynes can be identified. All statistical analyses were made in R.2.15.0, using the program's standard package (R Core Development Team, 2012).

\section{RESULTS}

\subsection{Sex and caste allocation}

We analyzed a total of 3,209 individuals of $M$. interrupta and 3,526 individuals of $M$. seminigra. The combs varied in the number of brood cells produced across the months. The highest number of individuals analyzed per month was of 239 in M. interrupta and 342 in $M$. seminigra, while the lowest number was of 44 in $M$. interrupta and 43 in $M$. seminigra (mean $=145.86, \mathrm{SD}= \pm 44.5$ for $M$. interrupta; mean $=176.3, \mathrm{SD}= \pm 58.47$ for $M$. seminigra).

In both species, gynes were produced during all the observed months. On the other hand, males did not occur in 2 (May and July) out of the 22 months analyzed for $M$. interrupta, and 4 (February, April, May and September) out of the 20 months analyzed for $M$. seminigra. Monthly gyne proportion in $M$. interrupta varied from 2 to $16.8 \%$ (mean $=10.3, \mathrm{SD}= \pm 4.07)$, while monthly male proportion, from 0 to $43.2 \%$ (mean $=12$,
$\mathrm{SD}= \pm 11.48)$. In $M$. seminigra, monthly gyne proportion varied from 1.2 to $20.6 \%$ (mean= $8.4, \mathrm{SD}= \pm 4.73$ ), and that of males, from 0 to $18.5 \%$ (mean $=3.8, \mathrm{SD}= \pm 4.92)$.

In $M$. interrupta, female segregation did not fit to the expected ratio of three workers to one gyne in any of the analyzed months $\left(\chi^{2}>3.84, P<0.05\right)$. In $M$. seminigra, segregation of $3: 1$ occurred in 2 out of 20 months ( $\chi^{2}=1.89$ and $\left.2.57, P>0.05\right)$. In both species, there was no evidence for the production of diploid males during the studied period $\left(\chi^{2}>3.84, P<0.05\right)$. We also found that male proportion was not correlated to that of gynes in both $M$. interrupta $(t=-0.418 ; P=0.54)$ and $M$. seminigra $(t=0.07 ; P=0.88)$.

\subsection{Influence of climatic factors on caste allocation}

During the study period, the highest value of cumulative rainfall registered over those months was of $404.8 \mathrm{~mm}$, and the lowest was of $13.3 \mathrm{~mm}$ (mean $=200.59, \mathrm{SD}= \pm 109.46$ ), while the monthly average of hours of sunshine fluctuated from 2.8 to 7.7 (mean=5.3; $\mathrm{SD}= \pm 1.22)$. The medium temperature varied from 26 to $28.8{ }^{\circ} \mathrm{C}$ (mean= $27.4 ; \mathrm{SD}= \pm 0.73$ ); and the air humidity, from 75.6 to $88.4 \%($ mean $=83.6, \mathrm{SD}= \pm 3.64)$.

In $M$. interrupta, we observed a strong and negative correlation between gyne proportion and cumulative rainfall after accounting for the other environmental variables, which explained $51 \%$ of the monthly variation in gyne number $(t=-2.852 ; P=0.01)$ (Figure 1). However, we did not find a significant relation between gyne proportion and monthly averages of temperature $(t=1.648 ; P=0.12)$, daily hours of sunshine ( $t=$ $-1.910 ; P=0.07)$, and air humidity $(t=1.940$; $P=0.07)$. This either means an absence of relation between those variables or that the high correlation between the climatic factors masked the effect of the other variables than rainfall. In $M$. seminigra, on the other hand, gyne proportion was not significantly correlated to temperature $(t=1.805 ; P=0.09)$, rainfall $(t=-0.658 ; P=$ $0.52)$, daily hours of sunshine $(t=-0.941 ; P=$ $0.36)$, or humidity $(t=1.311 ; P=0.21)$. 


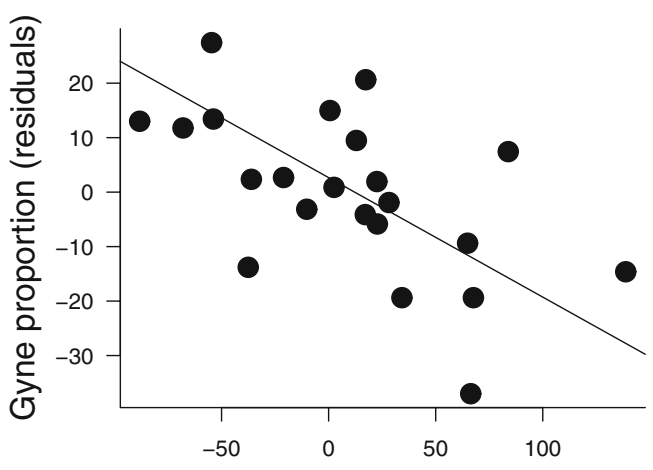

Cumulative rainfall (residuals)

Figure 1 Partial regression between gyne proportion in hives of $M$. interrupta and cumulative rainfall. Each graph point represents a month. Gyne proportion (percent) was calculated as the total number of gynes divided by the total number of females produced in a given month. Gyne proportion is negatively correlated to the cumulative rainfall (millimeters), after accounting for other climatic variables $\left(R^{2}=0.51 ; t=-2.852 ; P=0.01\right)$

\section{DISCUSSION}

\subsection{Natural patterns of sex and caste allocation in $M$. interrupta and $M$. seminigra}

Our results corroborate previous descriptions of a floating gyne proportion that is lower than the predicted by the main hypotheses on caste determination in Melipona spp. but still higher than in other bee species. Although gynes produced might be potential replacements in case of mother queen loss or swarming (Kerr et al. 1966), these events occur in a low frequency and the great majority of Melipona gynes are killed by workers just a few days after they emerge (Wenseleers et al. 2004). Ratnieks et al. (2001) and Wenseleers et al. (2003) proposed that queen excess is not advantageous at all for the colony, but instead it is the outcome of caste conflicts. Since female larvae can increase their fitness through direct reproduction by becoming queens and brood-rearing peculiarities of Melipona bees diminish worker control over caste fate, more female larvae could selfishly turn into queens. Even though the predictions of caste conflict apply to several contexts, more empirical studies are necessary to evaluate this hypothesis.

We also verified that male production was continuous throughout the year, but it was not correlated to gyne proportion in both $M$. interrupta and M. seminigra. Since a synchrony in the number of males and gynes could be expected for reproduction purposes, male production - just as gyne proportion - might not be related only to swarming (Moo-Valle et al. 2001). For instance, the conflict between workers and queens over male parentage in Melipona can result in short periods with intense male production by workers and long periods with a few males being produced only by queens (Velthuis et al. 2005). Additionally, asynchrony of reproductives production in colonies might be a strategy to avoid endogamy (Carvalho-Zilse and Kerr 2004; Kerr et al. 1996).

\subsection{Different responses to environmental factors in caste allocation of Melipona bees}

Here, we demonstrated a strong association between caste allocation in $M$. interrupta and a climatic seasonal factor. Monthly gyne proportion was inversely proportional to cumulative rainfall in colonies of $M$. interrupta. It is well established that patterns of flowering in tropical seasonal forests are usually correlated to annual variation in rainfall (Baker et al. 2008; ChangYang et al. 2012; Morellato et al. 2000). In the case of rainforests, it has been demonstrated that there is a negative correlation between plant phenology in general and rainfall, in which the peaks of plant production take place in the less rainy season (Heideman 1989; Huete et al. 2006; Sakai 2001; Smith-Ramirez and Armesto 1994). Moreover, foraging flights are hampered by rainfall in $M$. interrupta, which diminish colony food resources in rainy months (Marques-Souza 1996). Therefore, it is likely that rainfall interferes in gyne proportion by limiting food availability for bees. 
In contrast, despite the well-studied influence of climatic factors on flowering patterns, we did not find a significant relation between gyne proportion in $M$. seminigra and any of the analyzed environmental variables. Here, we propose that the different responses of $M$. interrupta and $M$. seminigra regarding caste allocation are at least partially due to their different foraging habits. Both species collect pollen and nectar from different plant species throughout the year but concentrate their foraging on a few species (Marques-Souza et al. 2002; Marques-Souza 1996; Oliveira et al. 2009). However, during the rainiest months of the year, $M$. interrupta explores an even smaller diversity of food sources, whereas this effect is not observed in M. seminigra foraging (Marques-Souza 1996).

Previous palynological studies with $M$. interrupta and $M$. seminigra at our study site provided data on the diversity of plants visited by these species for pollen collection throughout the year (Marques-Souza et al. 2002; Marques-Souza 1996). Using corresponding meteorological data from INMET, we found a marginally significant effect of monthly cumulative rainfall on the diversity of plants (number of genera) visited by $M$. interrupta for pollen collection (linear regression; $\left.r^{2}=0.24 ; F=4.52 ; P=0.05\right)$. Nevertheless, regressing the diversity of plants visited by $M$. seminigra on the same seasonal factor revealed no relation $(F=1.15 ; P=0.31)$.

We hypothesize that the diversity of food sources might affect gyne proportion in two ways. Due to the limited options of food sources for more specialist bees, there may be less food available for them in months of low flowering. Thus, a lower amount of food would be distributed in most brood cells, and it is known that a suboptimal food quantity decreases gyne number in the brood-possibly by repressing the expression of gyne phenotype (Camargo et al. 1976; Kerr et al. 1966; Maciel-Silva and Kerr 1991). Alternatively, different food sources may generate qualitative differences in brood feeding. Thereby, the production/consumption of important components for gyne growth and differentiation (as geraniol, for instance, Jarau et al. 2010) might be limited for more specialist bees in periods of low flowering, which would also constrain the expression of gyne phenotype. Either way, caste allocation in such species would be subject to an indirect effect of environmental factors. Interestingly, caste differentiation in Apis also depends on food availability, although in that case it is tightly controlled by nurse workers (Linksvayer et al. 2011). Thus, although Apis and Melipona have fundamentally distinct caste determination systems, indirect effects seem to be important in both cases.

Seasonal variation in gyne proportion was also found in Melipona beecheii (Moo-Valle et al. 2001), and a lower proportion of gynes was observed during the wet season in Brazil in four species: Melipona quadrifasciata Lepeletier; Melipona schencki Gribodo; Melipona fasciata Latreille; and Melipona marginata Lepeletier (Kerr 1950). Nevertheless, an absence of seasonal effects on gyne proportion has been reported for Melipona favosa Fabricius (Sommeijer et al. 2003), Melipona trinitatis Cockerell (Sommeijer et al. 2003), and Melipona compressipes fasciculata (Morais et al. 2006). Information about pollen sources is available for only three of the cited species, but they support our predictions about gyne proportion and diversity of pollen sources. Studies with $M$. marginata and $M$. quadrifasciata showed low levels of diversity in pollen collecting (Kleinert-Giovannini and ImperatrizFonseca 1987; Ramalho et al. 1989), and it was observed a seasonal variation in pollen sources of M. quadrifasciata (Guibu et al. 1988). On the other hand, M. compressipes fasciculata was found to be as generalist as honeybees and nonMelipona stingless bees (Kerr et al. 1986; Absy et al. unpublished data).

In conclusion, our study showed that temporal variation in caste allocation in $M$. interrupta is related to environmental conditions, which probably involves an indirect effect through restriction of food availability. We also provided evidence that caste allocation is more responsive to environmental factors in $M$. interrupta than in $M$. seminigra. This, together with literature data, suggests that there is variation in such response across Melipona species. We hypothesize that this variation may reflect the diversity of food sources 
used by Melipona bees, so that more specialized species would be more responsive to such factors. Thus, although Melipona bees may share a common mechanism of caste determination, species respond differently to environmental factors limiting this process according to their biological features.

\section{ACKNOWLEDGMENTS}

We thank the anonymous referees for providing useful comments on earlier versions of this manuscript. We also thank the sponsoring agencies FAPEAM and $\mathrm{CNPq}$ for financial support.

Effets variables des facteurs environnementaux sur la répartition des castes chez deux espèces de Melipona amazoniennes

Espèce eusociale / approvisionnement / Meliponini / reine / abeille sans aiguillon / facteur environnemental

Unterschiede in der Auswirkung von Umweltfaktoren auf die Kastenproportionen bei zwei im Amazonasgebiet vorkommenden Meliponen

eusoziale Insekten / Futtersammeln / Meliponini / Königinnen / Stachellose Bienen

\section{REFERENCES}

Baker, I.T., Prihodko, L., Denning, A.S., Goulden, M., Miller, S., da Rocha, H.R. (2008) Seasonal drought stress in the Amazon: reconciling models and observations. J. Geophys. Res. doi:10.1029/ 2007JG000644

Bonetti, A.M. (1984) Efeitos do hormônio juvenil no desenvolvimento ovariano de Melipona quadrifasciata. Rev. Bras. Biol. 44, 509-516

Bourke, A.F.G., Ratnieks, F.L.W. (1999) Kin conflict over caste determination in social Hymenoptera. Behav. Ecol. Sociobiol. 46, 287-297

Camargo, C.A., Almeida, M.G., Parra, M.G.N., Kerr, W.E. (1976) Genetics of sex determination in bees. IX. Frequencies of queens and workers from larvae under controlled conditions (Hymenoptera: Apoidea). J. Kansas Entomol Soc 49(1), 120-125

Carvalho-Zilse, G.A., Kerr, W.E. (2004) Substituição natural de rainhas fisogástricas e distância de vôo dos machos em Tiuba (Melipona compressipes fasciculata Smith, 1854) e Uruçu (Melipona scutellaris) Latreille, 1811) (Apidae, Meliponini). Acta Amaz. 34(92), 649-652

Carvalho-Zilse, G.A., Porto, E.L., Silva, C.G.N., Pinto, M.F.C. (2007) Atividades de vôo de operárias de Melipona seminigra (Hymenoptera: Apidae) em um sistema agroflorestal da Amazônia. Bioscience Journal 23(1), 94-99

Chang-Yang, C.H., Lu, C.L., Sun, I.F., Hsieh, C.F. (2012) Flowering and fruiting patterns in a subtropical rain forest. Taiwan. Biotropica . doi:10.1111/ j.1744-7429.2012.00911.x

Francini, I.B., Gross, M.C., Nunes-Silva, C.G., Carvalho-Zilse, G.A. (2011) Cytogenetic analysis of the Amazon stingless bee Melipona seminigra merrillae reveals different chromosome number for the genus. Sci. Agr. 68(5), 592-593

Francini, I.B., Nunes-Silva, C.G., Carvalho-Zilse, G.A. (2012) Diploid male production of two Amazonian Melipona bees (Hymenoptera: Apidae). Psyche 2012, 1-7

Grimaldi, D., Engel, M.S. (2005) Evolution of the Insects. Cambridge University Press, New York

Guibu, L.S., Ramalho, M., Kleinert-Giovannini, A., Imperatriz-Fonseca, V.L. (1988) Exploração dos recursos florais por colônias de Melipona quadrifasciata (Apidae, Meliponinae). Rev. Bras. Biol. 48(2), 299-305

Hartfelder, K., Makert, G.R., Judice, C.C., Pereira, G.A.G., Santana, W.C., Dallacqua, R., Bitondi, M.M.G. (2006) Physiological and genetic mechanisms underlying caste development, reproduction and division of labor in stingless bees. Apidologie 37, 144-163

Heideman, P.D. (1989) Temporal and spatial variation in the phenology of flowering and fruiting in a tropical rainforest. J. Ecol. 77, 1059-1079

Huete, A.R., Didan, K., Shimabukuro, Y.E., et al. (2006) Amazon rainforests green-up with sunlight in dry season. Geophys. Res. Lett. 33(6), 2-5

Jarau, S., van Veen, J.W., Twele, R., Reichle, C., Gonzales, E.H., Aguilar, I., Francke, W., Ayasse, M. (2010) Workers make the queens in melipona bees: identification of geraniol as a caste determining compound from labial glands of nurse bees. J. Chem. Ecol. 36(6), 565-569

Kerr, W.E. (1950) Genetic determination of castes in the genus Melipona. Genetics 35(2), 143-152

Kerr, W.E. (1996) Biologia e manejo da tiuba: a abelha do Maranhão. EDUFMA, São Luíz

Kerr, W.E., Nielsen, R.A. (1966) Evidence that genetically determined Melipona queens can become workers. Genetics 54(3), 859-866

Kerr, W.E., Stort, A.C., Montenegro, M.J. (1966) Importância de alguns fatores ambientais na determinação das castas do gênero Melipona. An. Acad. Bras. Cienc. 38(1), 149-168

Kerr, W.E., Akahira, Y., Camargo, C.A. (1975) Sex determination in bees. IV. Genetic control of juvenile hormone production in Melipona quadrifasciata (Apidae). Genetics 81, 749-756 
Kerr, W.E., Absy, M.L., Marques-Souza, A.C. (1986) Espécies nectaríferas e poliníferas utilizadas pela abelha Melipona compressipes fasciculata (Meliponinae, Apidae), no Maranhão. Acta. Amaz. 16/17, 145-156

Kerr, W. E., Carvalho-Zilse, G. A., Nascimento, V. A. (1996) Abelha Uruçu: Biologia, Manejo e Conservação. Fundação Acangaú, Paracatu

Kleinert-Giovannini, A., Imperatriz-Fonseca, V.L. (1987) Aspects of the trophic niche of Melipona marginata marginata Lepeletier (Apidae, Meliponinae). Apidologie 18(1), 69-100

Koedam, D. (1999) Production of queens, workers and males in the stingless bee Melipona favosa (Apidae: Meliponinae): patterns in time and space. Neth. J. Zool. 49(4), 289-302

Linksvayer, T.A., Kaftanoglu, O., Akyol, E., Blatch, S., Amdam, G.V., Page Jr., R.E. (2011) Larval and nurse worker control of developmental plasticity and the evolution of honey bee queen-worker dimorphism. J. Evol. Biol. 24, 1939-1948

Maciel-Silva, V.L., Kerr, W.E. (1991) Sex determination in bees. XXVII. Castes obtained from larvae fed homogenized food in Melipona compressipes (Hymenoptera, Apidae). Apidologie 22, 15-19

Marques-Souza, A.C. (1996) Fontes de pólen exploradas por Melipona compressipes manaosensis (Apidae: Meliponinae), abelha da Amazônia central. Acta Amaz. 26(1), 77-86

Marques-Souza, A.C., Miranda, I.P.A., Moura, C.O., Rabelo, A., Barbosa, E.M. (2002) Características morfológicas e bioquímicas do pólen coletado por cinco espécies de meliponíneos da Amazônia Central. Acta. Amaz. 32, 217-229

Mitesser, O., Weissel, N., Strohm, E., Poethke, H.J. (2007) Optimal investment allocation in primitively eusocial bees: a balance model based on resource limitation of the queen. Insectes. Soc. 54(3), 234-241

Moo-Valle, H., Quezada-Euán, J.J.G., Wenseleers, T. (2001) The effect of food reserves on the production of sexual offspring in the stingless bee Melipona beecheii (Apidae, Meliponini). Insectes. Soc. 48(4), 398-403

Morais, M.M., Nascimento, F.S., Pereira, R.A., Bego, L.R. (2006) Colony internal conditions related to caste production in Melipona compressipes fasciculata (Apidae, Meliponini). Insectes. Soc. 53(3), 265-268

Morellato, L.P.C., Talora, D.C., Takahasi, A., Bencke, C.C., Romera, E.C., Ziparro, V.B. (2000) Phenology of Atlantic rain forest trees: a comparative study 1 . Biotropica 32(4b), 811-823
Oliveira, F.P.M., Absy, M.L., Miranda, I.S. (2009) Recurso polínico coletado por abelhas sem ferrão (Apidae, Meliponinae) em um fragmento de floresta na região de Manaus-Amazonas. Acta. Amaz. 39(3), 505-518

Oliveira, F.L., Dias, V.H.P., Costa, E.M., Filgueira, M.A., Sobrinho, J.E. (2012) Influência das variações climáticas na atividade de vôo das abelhas jandairas Melipona subnitida Ducke (Meliponinae). Rev. Ciencia Agron. 23(3), 598-603

Ramalho, M., Kleinert-Giovannini, A., ImperatrizFonseca, V.L. (1989) Utilization of floral resouces by species of Melipona (Apidae, Meliponinae): floral preferences. Apidologie 20, 185-195

Ratnieks, F. (2001) Heirs and spares: caste conflict and excess queen production in Melipona bees. Behav. Ecol. Sociobiol. 50(5), 467-473

Ratnieks, F.L.W., Monnin, T., Foster, K.R. (2001) Inclusive fitness theory : novel predictions and tests in eusocial Hymenoptera. Ann. Zool. Fenn. 38, 201-214

Sakai, S. (2001) Phenological diversity in tropical forests. Popul. Ecol. 43(1), 77-86

Silva, M.D.E., Ramalho, M., Rosa, J.F. (2011) Por que Melipona scutellaris (Hymenoptera, Apidae) forrageia sob alta umidade relativa do ar? Iheringia Ser. Zool. 101(1-2), 131-137

Smith-Ramirez, C., Armesto, J.J. (1994) Flowering and fruiting patterns in the temperate rainforest of Chiloé, Chile-ecologies and climatic constraints. J. Ecol. 82(2), 353-365

Sommeijer, M.J., de Bruijn, L.L.M., Meeuwsen, F.J.A.J., Martens, E.P. (2003) Natural patterns of caste and sex allocation in the stingless bees Melipona favosa and $M$. trinitatis related to worker behaviour. Insectes Soc 50(1), 38-44

van Veen, J.W., Arce, H.G.A., Sommeijer, M.J. (2004) Production of queens and drones in Melipona beecheii (Meliponini) in relation to colony development and resource availability. Proc. Neth. Entomol. Soc. Meet. 15, 35-39

Velthuis, H.H.W., Koedam, D., Imperatriz-Fonseca, V.L. (2005) The males of Melipona and other stingless bees, and their mothers. Apidologie 36, 169-185

Wenseleers, T., Ratnieks, F.L.W., Billen, J. (2003) Caste fate conflict in swarm-founding social Hymenoptera: an inclusive fitness analysis. J. Evol. Biol. 16(4), 647-658

Wenseleers, T., Hart, A.G., Ratnieks, F.L.W., QuezadaEuan, J.J.G. (2004) Queen execution and caste conflict in the stingless bee Melipona beecheii. Ethology 110(9), 725-736 